\title{
Questioning the Leadership and Preferences of Regional Heads in Determining Minimum Wage
}

\author{
Adnan Hamid \\ Deputy Dean 2 of the Faculty of Law, Universitas Pancasila, J1. Srengseng Sawah, Jagakarsa, Jakarta \\ Selatan - 12640, Indonesia
}

\begin{abstract}
This study aims to identify and questioning the leadership and preferences of regional heads in setting minimum wage policies. The research method used is normative juridical legal research, using a statutory approach in the national labor law system. The results showed that the regional head has the authority to set the minimum wage for workers / laborers to meet the needs of a decent life (KHL) by determining the UMSP and UMSK. As public leaders, regional heads are expected to have transformational leadership behavior, be able to present the vision, mission, and task completion plans as well as problem solvers, produce a positive work environment to strengthen professionalism, transparency in decision making, and trust. Then the regional head is expected to be able to make innovative efforts related to human resource development, creative industry development and programs that support small and medium enterprises so that they can be an option in overcoming labor problems
\end{abstract}

Keywords: The National Labor Law System, Regional Heads, Transformational Leadership, Minimum Wage.

\section{Introduction}

Currently, many experts, policymakers, supporters and employers argue that the importance of workers' welfare (Guest, 2008 in Budd, \& Spencer (2014: 162). But on the other hand, Ehrenreich (2001) and Harney (2008) in Budd \& Spencer (2014: 182) states that there is still exposure / sharpening of practice in the business world related to labor which is a problem such as low wages, long working hours and dangerous working conditions experienced by some workers. aiming to eradicate poverty has become a specific agenda in various countries in the world and Indonesia is no exception. In developed countries, low-wage workers are predominantly employed in places such as restaurants, hotels, retail outlets, nursing homes, hairdressers, on agriculture and in the textile, clothing and food processing industries. Whereas in developing countries those who work in agriculture and the textile, garment, leather and footwear (TGLF) industries - including as part of global supply chains - are the main employers of minimum wage workers (Interrnational Labor Organization, 2016: 3). Then, efforts to raise the minimum wage can be seen as one way of supporting lowwage workers towards higher minimum wages. Therefore, wages have a very important and significant importance and meaning for workers / laborers, entrepreneurs, government and society in general.

For workers / laborers and their families, they are very dependent on the wages they receive in order to fulfill primary and secondary needs in order to live a decent life, such as meeting clothing, food, housing and other needs. From the entrepreneur's perspective, wages are an economic factor that must be taken into account carefully in the context of managing the capital they have in order to get the best possible results. Meanwhile, from the Government's perspective, wage policies are closely related to meeting the welfare standards of the people. Meanwhile, from the perspective of the wider community, the view is that the wage system policy set by the government must have significant implications for the life of the nation and state.In Indonesia, the authority to determine the minimum wage is the Regional Head, the Governor as stated, Article 49 of the Government Regulation (PP) Wages as follows: The Governor can determine the provincial and / or district / city sectoral minimum Wages based on the agreement between the employers' association and the trade / labor union. in the sector concerned. Further provisions regarding sectoral minimum wages are further regulated in the Minister of Manpower Regulation Number 15 of 2018 
concerning Minimum Wages. Including the Provincial Sectoral Minimum Wage (UMSP), and District / City Sectoral Minimum Wages (UMSK).

Then, in the context of the succession of regional head leadership in Indonesia, it is through the holding of Regional Head Elections (Pilkada). In 2020, the 2020 simultaneous regional elections will be held in 270 regions in Indonesia, covering 9 provinces, 224 regencies and 37 cities. The 2020 Pilkada is the third time it has been held in Indonesia, the first Pilkada was held in 2015, the second Pilkada in 2017, and the third Pilkada in 2018 (Kompas Daily, 12/9/2020 page 3, Politics \& Law,). The fourth Pilkada, the implementation of voting and counting of votes at the polling station (TPS) was held on December 9, 2020 (Mudassir 2020).

In the past several elections, political parties have often calculated and glanced at workers / laborers to gain votes because of the bargaining position of workers / laborers as a barn of votes, the final voter list (DPT). However, ironically, issues related to the politicization of minimum wages in regional head elections (Pilkada) often occur, to gain votes, and when elected as regional heads, the issue of minimum wages tends to be ignored. The result was a number of masses of workers in various regions staged demonstrations in front of the offices of the regional heads, and they demanded an increase. Minimum Wage and becomes a problem every year.

Realizing the importance of wages and the position of a worker / laborer for the company, government and society, it is necessary to provide legal protection for workers / labor. According to Hamid (2020: 236), the main basis of labor and employment law in Indonesia is as regulated in the 1945 Constitution Article 27 paragraph 2 which states that every citizen has the right to work and a decent living. Then, in order to realize a rule of law, one of which requires a legal instrument that is used to regulate balance and justice in all areas of life and people's livelihoods through laws and regulations without neglecting the function of jurisprudence (Hamid, 2020: 236-237). Thus, labor and employment laws in Indonesia must be obeyed by all citizens.

Based on the importance of the wage system policy and the strategic role of the Regional Head who has the authority to determine and determine the minimum wage, it is the significance of this study. Therefore, the problem raised by researchers in this study is "Questioning the Leadership and Preferences of Regional Heads in Determining Minimum Wage " which are related to the policies of the Regional Heads to provide legal protection to workers / laborers as contained in Article 27 (2) of the Constitution. 1945, and Law Number 13 Year 2003 especially regarding minimum wages.

\section{Literature Review}

In general, a leader can be interpreted as someone who has the ability to direct his subordinates to achieve goals. A leader is a person who has skills and strengths, especially skills and strengths in one area, so that he is able to influence others to jointly carry out certain activities, for the sake of achieving one or more goals (Kartono, 1994: 33). According to Jones \& George (2013: 316), a leader is a person who exerts such influence, and leadership is a way that a person uses to influence others and inspire, motivate, and direct their activities to help achieve group and organizational goals. Political leaders show their capacity as creative problem solvers and have the ability to increase the visibility of the output and outcomes of the policy process (McFarland 1987).

Tucker (1995) and Nye (2008) define political leadership as the performance of five related tasks: (1) the discursive formation of the political community they wish to lead; (2) identification of social problems and challenges that require public action; (3) development of innovative, feasible and robust policy solutions; (4) mobilize broad support for the implementation of innovative, feasible and robust policy solutions i; and (5) highlight the public value that results from making public policy. Then, Morrell, K., \& Hartley, J. (2006: 484) define political leaders as follows: (1) democratically elected, (2) representative, (3) vulnerable to annulment of elections, and (4) operating in in, as well as influencing the legal and constitutional frameworks, (5) the source of their authority is the mandate: 'permission to govern according to declared policy, which is formally granted by the electorate and membership of the electorate is regulated in law, extending to all citizens who have voting rights, in certain constituencies.

According to Colquitt, Lepine \& Wilson (2011: 496), leadership is the ability to decide what to do, and then make other people want to do it. According to Richards \& Eagel (1986), leadership is a way of articulating a 
vision, realizing value, and creating an environment to achieve something (Yukl, 2010: 4). According to House et.al. (1999) in Yukl (2010: 4) ,, leadership is the ability of individuals to influence, motivate, and make others able to contribute to the effectiveness and success of the organization. According to Robbins and Judge (2015: 410), leadership is the ability to influence an organization. group towards achieving a vision or set of goals.

Whereas Simon Gächter \& Elke Renner, 2018: 2) states that leaders - politicians, government officials, and managers - can be role models, leaders behave as positive role models for what is deemed appropriate and thus can shape their followers' beliefs about the behavior of others . On the other hand, leaders who behave too selfishly and thirst for power tend to consume community privileges in unreasonable ways, such as corrupt behavior, collusion and nepotism. This negative leader's behavior can encourage the person or work environment where the leader is in power so that this can foster confidence that the people they lead will do the same.

This condition will exacerbate the problem because people's behavior tends to be shaped by the example of a leader, which is an axiom.Leaders in the public sector have a different role from leaders in the private sector, and based on the results of studies by experts that leadership can improve individual and organizational performance in public institutions (Bellé 2013; Mikkelsen, Jacobsen \& Andersen 2015; Oberfield 2014). According to Tummers and Knies (2016) there are four approaches to public leadership as follows: (1) Accountability leadership, justifying action to stakeholders; (2) Leadership that follows the rules, acts according to the rules; (3) Political loyalty leadership, advancing the will of politicians; and (3) Leadership network government, connecting with others.

In the context of political leadership, Burns (1978) is an expert who initiated transformational leadership in his groundbreaking study which stated that transformational leadership forms close relationships with all of their followers, stimulates awareness of their true needs and enhances their vision that is closely related through four elements. meta leadership as follows: perception, articulation, belief and empathy - interacting in "visioning". The implication of transformational leadership is to change leadership, ultimately to be moral in that it increases the level of human behavior and ethical aspirations of both the leader and the one being led, and thus has a transforming effect on both (Burn, 1978: 20),..Since its introduction by Burns (1978) and Bass (1985), transformational leadership theory has evolved to describe the four dimensions of leader behavior. According to Bas \& Bass (2009: 432), the dimensions of transformational leader behavior consist of:

1. Charisma which was later renamed Idealized influence (Rafferty \& Griffin, 2004:330), the extent to which leaders behave in a charismatic manner that causes followers to identify with them; . Weber (1968) in( Rafferty \& Griffin, 2004:33) stated that charisma involves five components including an extraordinarily gifted person; a social crisis; a set of ideas providing a radical solution to a problem; a set of followers who are attracted to the exceptional person and believe that the leader is linked to transcendent powers; and the validation of the leader's extraordinary gifts through repeated success.

2. Inspirational motivation, the extent to which leaders articulate a vision that is attractive to followers. According to Yukl (2010) that inspiration refers to "the extent to which a leader stimulates enthusiasm among subordinates for the work of the group and says things to build subordinate confidence in their ability to perform assignments successfully and attain group objectives.'

3. Intellectual stimulation, the degree to which leaders challenge assumptions, take risks, and collect followers' ideas; and the effects of intellectual stimulation are seen in increases in followers' abilities to conceptualize, comprehend, and analyze problems and in the improved quality of solutions that they generate (Bass \& Avolio, 1990).

4. Individual consideration, the extent to which leaders pay attention to the needs of followers, act as mentors or coaches, listen to follower concerns, and personal recoqnition.. The leader gives personal attention to followers by treating them "differently but equitably" (Bass \& Avolio, 1990). In exhibiting individualized consideration, the leader first identifies the individual needs and abilities of followers and then mentors and coaches them, and also uses delegation, and analyze problems from their personal perspectives, encourages creativity, innovation, and challenge conventional wisdom (Bass \& Avolio, 1990). Acoording to Rafferty \& Griffin, 2004:334), personal recognition occurs 
when a leader indicates that he or she values individuals' efforts and rewards the achievement of outcomes consistent with the vision through praise and acknowledgment of followers' efforts. We define personal recognition as: The provision of rewards such as praise and acknowledgement of effort for achievement of specified goals.

Transformational leadership is meant as a leadership model used across the spectrum of politics, education, entertainment, finance, technology, and other industries because transformational leaders help define and outline goals through vision and mission and have the ability to analyze circumstances and articulate the improvements needed immediately. (DiFranza, 2019). According to Wheelen and Hunger (2012: 60), transformational leaders are leaders who have many characteristics, for example, leaders who provide change and progress in an organization by providing a vision for change, positive attitudes, and leadership strength for the progress of the company so that transformational leaders are able to provide these orders and orders are highly respected by his subordinates and greatly influence the formulation of work strategies and their implementation in the organization.

According to experts in Iqbal (2016: 611 - 612) that transformational leaders present the vision, mission, and task completion plans and they reduce ambiguity, uncertainty and explain to overcome challenges in a more feasible way. Then, the transformational style strengthens achievement, justice, and justice so that transformational leadership can produce a positive work environment to strengthen professionalism, and always characterizes transparency about decision making that shows fairness and trustworthiness (Iqbal, 2016: 611 - 612). On the other side, Budd \& Spencer (2014: 191), working as a source of freedom for workers and society is related to the idea of work as an arena for human creativity in the form of opportunities to acquire, develop, hone and utilize skills at work is a very important element of a comprehensive approach to welfare. workers. According to Ravi \& Raja (2016: 89-91), the worker welfare program has the aim of improving the physical and psychological well-being of workers / laborers as well as measures of labor welfare prove to be an important factor when compared to other factors in the organization.

According to experts in Lollo \& O'Rourke (2020: 24-25) that the classic way to provide incentives to workers is by "piece rate", which is paying workers according to their marginal productivity, for example (wages of workers in factories) or being paid corresponds to a per-group rate or "group rate" such as farm picking wages which are jobs commonly studied in team-based wage designs. According to Government Regulation (PP) Number 78 of 2015 concerning Wages, the wage policy is aimed at achieving income that meets a decent living for Workers / Laborers. A decent income as referred to is the amount of revenue or income a Worker / Laborer receives from the results of his work so that he is able to meet the needs of the Worker / Laborer and his family fairly. According to Government Regulation (PP) Number 78 of 2015 concerning Minimum Wage Formula, it explains that the calculation of the minimum wage uses the following formula:

$\mathrm{UMn}=\mathrm{UMt}+\{\mathrm{UMt} \times($ Inflasit $+\% \Delta \mathrm{PDBt}\}$

Note:

- Umn: The minimum wage (Upah minimum) to be determined

- Umt: Minimum wage (Upah minimum) for the current year

- Inflasit: Inflation calculated from September of the previous year to September of the current year

- $\Delta$ PDBt: Gross Domestic Product Growth (Pertumbuhan Produk Domestik Bruto) in the third and fourth quarters of the previous year and the first and second quarters of the current year

Pilkada in 2015 until the fourth Pilkada which will be held on December 92019 simultaneously in Indonesia is how the leadership and preferences / preferences of regional heads to workers / laborers, policies in determining and setting minimum wages. This question becomes very significant because it refers to empirical experience so far that what happens is that the policies of regional heads after serving as public leaders in the regions generally tend not to be optimal in determining and determining a proper minimum wage, for example the Minimum Wage in Daerah Khusus Ibukota (DKI Jakarta is still below what is being fought for. by the workers (Kuncahyo, 2016), and the dynamics of labor demands by holding demonstrations in various regions continues and takes place every year. 
Based on the understanding of the notion of leadership and preferences / partisanship of the Regional Head regarding the minimum wage, it is the significance of this study. Therefore, the Regional Head is expected to have transformational leadership, visionary leader behavior, show his capacity as a problem solver, the ability to increase the visibility of the output and outcomes of the policy process, have a logical and structured work plan concept and be able to implement it, be able to advance the region according to its potential. and the resources they have, are able to work in a measured and realistic manner, are able to eliminate and reduce corrupt, collusive, and nepotistic behaviors and have preferences / partisans of the Regional Head in determining policies.

\section{Methodology}

The research method used is normative juridical legal research that uses the statutory approach in the national labor law system. According to Soekanto \& Sri Mamudji (2006), the normative juridical legal research method is legal research which is carried out by examining library materials or secondary data, and the particularity of the analysis of this research is carried out descriptively (Babbie, 1989). Empirical normative legal research examines the implementation or implementation of positive legal provisions (legislation) and contracts factually in any particular legal event that occurs in society in order to achieve predetermined goals. The study aims to ascertain whether the results of the application of legal events in concreto are in accordance or not in accordance with statutory provisions or contractual provisions. Empirical (applied) normative legal research begins with written positive legal provisions (laws) that are enforced on in-concreto legal events in society. The implementation or implementation is manifested through real actions and legal documents). Based on the results of the application, it can be understood whether the provisions of the law or contract provisions have been implemented properly or not (Muhammad, 2004: 53-54).

Then, the steps taken are literature studies that examine (especially) secondary data in the form of: primary legal materials that are authoritative in nature, meaning they have authority, namely library materials that have juridical binding power (Moleong. 2002: 4) and secondary legal materials. Primary legal materials include the 1945 Constitution of the Republic of Indonesia, Law Number 13 of 2003 concerning Manpower, Law of the Republic of Indonesia Number 23 of 2014 (Law of the Republic of Indonesia Number 23 of 2014) concerning Regional Government, Regulation of the Minister of Manpower and Transmigration (Permenakertrans) No 7 of 2013 concerning Minimum Wages, Government Regulation (PP) Number 78 of 2015 concerning Wages and various other related laws and regulations. Secondary legal materials are obtained through the study of research results, books and scientific journals, jurisprudence, and other library materials that discuss the Minimum Wage for Labor.

\section{Discussions and Results}

\subsection{Labor Law Review}

There are two important topics that concern the government in encouraging the strengthening of the community economy. First, regarding wage policies that are fair, simple and according to projections. Second, the People's Business Credit (KUR) policy which is cheaper and more extensive. "The main objective of determining the Provincial Minimum Wage is to open the widest possible opportunity for employment and improve the welfare of workers (Center for National Law Analysis and Evaluation, BPHN KEMENKUMHAM, 2018: 4). In this case, Law Number 13 of 2003 concerning Manpower is a legal instrument in Indonesia that regulates worker protection and aims to guarantee basic rights of workers / labor and guarantee equal opportunity and treatment without discrimination on any basis to realize worker welfare. / laborers and their families while paying attention to the progress of the business world. However, if you look at the 2018 EODB employment indicator survey, there are still many labor rights that have not been fulfilled by companies or have not been regulated in laws and regulations. (World Bank, 2018: 127 131). Then, the foundation, principles, and objectives of the birth of Law Number 13 Year 2003 are as follows: Manpower development based on Pancasila and the 1945 Constitution of the Republic of Indonesia (Article 2); Principles and Manpower Development is carried out on the principle of integration through functional coordination across central and regional sectors (Article 3).

Then,. Article 4 concerning the purpose of the birth of Law Number 13 of 2003, namely Manpower Development aims to: 
1. Empower and utilize manpower optimally and humanely;

2. Realizing equal employment opportunities and provision of manpower in accordance with the needs of national and regional development;

3. Providing protection to workers in creating welfare; and

4. Increasing the welfare of workers and their families.

Furthermore, the term labor is very broad, which includes all people who are able to do work, whether they already have a job in a work relationship or as self-employed workers or who do not / do not have a job (Soepomo, 1999: 34). The work relationship referred to in the Manpower Law is the relationship between employers and workers, while the entrepreneur referred to in the law is the person who runs the company (Hamid, 2019: 5). Meanwhile, Manullang (2001: 3-5) states that the definition of labor is anyone who is able to carry out work, both inside and outside of a work relationship in order to produce services.

According to Law Number 13 of 2003, the definition of labor is anyone who is able to do work in order to produce goods and / or services both to meet their own needs and for the community (Article 1 paragraph 2). Meanwhile, the definition of Worker / labor is everyone who works and receives wages or other forms of remuneration (Article 1 paragraph 3). According to Kosidin (1996: 305), workers / laborers are part of the workforce who work in an employment relationship, under orders from the employer (can be individuals, entrepreneurs, legal entities or other bodies) and for their services in work they receive wages or rewards in other forms. Workers are called workers / laborers when they perform work in an employment relationship and are under orders from others by receiving wages or other forms of remuneration.

According to Waas, B. (2010: 45), the form of an employment relationship is the key to implementing the provisions, rules and principles of labor law. Workers who work under the orders of others by receiving wages or other forms of remuneration but not in an employment relationship, such as shoeshine workers, are not workers / laborers (Kosidin, 1996: 305). Thus, the definition of labor is broader. than workers. Workers are laborers, while laborers are not only workers (Soepomo, 1972: 6). According to Ford (2000), Law Number 13 of 2003 does not differentiate between white collar workers / laborers and blue collar workers / laborers.

The distinction between workers / laborers in this law is only based on gender (female and male workers / laborers) and age (workers / laborers), and this distinction is made not in the context of discrimination but to protect workers / laborers who are weak in body and to maintain the norms of decency (Ford, 2000: 6-8). Legal protection can be realized in material form (worker / labor welfare) but also in the form of preventing accidents, maintaining the health and safety of workers in carrying out work. According to experts in Budd \& Spencer (2014: 182), the definition of worker welfare is job satisfaction as a measure (Stride et al., 2007; Clark, 2011) and factors (skills, autonomy) that give workers the opportunity to achieve prosperity (Muñoz de Bustillo et al., 2011) and are described in detail as in Table 1 below:

Table 1: Domains of worker well-being: A comprehensive approach

\begin{tabular}{|l|l|l|}
\hline No & Domains of worker well-being & Measurements \\
\hline 1 & Pay and benefits & $\begin{array}{l}\text { - An adequate income including a 'living wage' and } \\
\text { basic benefits coverage } \\
\text { - Economic security via social safety nets }\end{array}$ \\
\hline 2 & Safety, health and body work & $\begin{array}{l}\text { - Protection against workplace hazards and risks } \\
\text { - Positive indicators of a worker's physical health } \\
\text { - Protection against unwanted intimacy and sexual } \\
\text { harassment }\end{array}$ \\
\hline 3 & Psychological and mental health & $\begin{array}{l}\text { - Avoidance of undue stress associated with work } \\
\text { - Avoidance of excessive effort and hours of work } \\
\text { - Positive levels of job satisfaction and self-esteem }\end{array}$ \\
\hline
\end{tabular}




\begin{tabular}{|c|c|c|}
\hline & & Identity \\
\hline 4 & Identity & $\begin{array}{l}\text { - Positive levels of self-identity and consistency with } \\
\text { life goals } \\
\text { - Pay, benefits and other markers of social standing } \\
\text { that contribute to positive identity } \\
\text { - Avoidance of excessive levels of emotional labour } \\
\text { and other sources of inauthenticity }\end{array}$ \\
\hline 5 & Freedom and voice & $\begin{array}{l}\text { - Freedom to quit and occupational choice } \\
\text { - Protections against discrimination, harassment, } \\
\text { abusive treatment and unfair dismissal } \\
\text { - Ability to form independent trade unions } \\
\text { - Workplace free speech protections }\end{array}$ \\
\hline 6 & Skill and creativity & $\begin{array}{l}\text { - Opportunities for skill development and use } \\
\text { - Avoidance of low complex and mundane work }\end{array}$ \\
\hline 7 & Autonomy over work & $\begin{array}{l}\text { - Opportunities to control how and what work is } \\
\text { done } \\
\text { - Opportunities to influence design and planning of } \\
\text { work }\end{array}$ \\
\hline 8 & Governance and ownership & $\begin{array}{l}\text { - Opportunities to participate in how work is } \\
\text { managed } \\
\text { - Opportunities to own productive assets }\end{array}$ \\
\hline 9 & Caring & $\begin{array}{l}\text { - Opportunities for caring for others } \\
\text { - Avoidance of conflicts that prevent the fulfilment } \\
\text { of caring responsibilities }\end{array}$ \\
\hline 10 & Serving others & $\begin{array}{l}\text { - Opportunities for serving others } \\
\text { - Avoidance of conflicts that interfere with ability to } \\
\text { serve others }\end{array}$ \\
\hline
\end{tabular}

Source: * Budd, J. W., \& Spencer, D. A. (2014:189)

Based on table 1, it can be interpreted that workers are entitled to a wage rate that allows them and their families to live at a level that is socially acceptable. Sufficient salary and allowances that are received as a whole are very important to support the physical life of workers / laborers and their families in order to meet the necessities of life.On the other hand, the work itself should not endanger workers physically and psychologically because hazardous work results in personal costs and public.In this context, workers' welfare must include standards of physical and psychological well-being, health and safety in the workplace. Then, the pursuit of higher wages and an increase in work-related benefits is very rational and can be justified by referring to the conceptualization of work identity because wages can motivate workers and have a direct impact on increasing the productivity of the company's business (Fehr, 2007 and Chang, 2014 in Lollo \& O ' Rourke, 2020: 24).

According to Mahasin, Naziah, \& Arifin (2020: 1), one form of implementation of the mandate of the 1945 Constitution in realizing a decent living, especially for workers, is the minimum wage policy based on Law (Undang - Undang) Number 13 of 2003 concerning Manpower which aims to provide protection for workers and their families. This is clearly stated in the consideration of letter (d) of Law Number 13 Year 2003 concerning Manpower, that labor protection is intended to guarantee the basic rights of workers and guarantee equal opportunity and treatment without discrimination on any basis to achieve welfare. Then, in 
terms of disharmony in work relations or labor unrest, it is largely the problem of low wage levels in Indonesia due to an abundant supply of labor, a very low level of labor skills, and on the one hand the government has an interest in and seeks to create and expand employment ( Mahasin, Naziah, \& Arifin, 2020:1) .

According to Permenakertrans No.7 of 2013 concerning Minimum Wages and Government Regulation (PP) Number 78 of 2015 concerning Wages, there are four types of minimum wages as follows:

1. Provincial Minimum Wage (Upah Minimum Provinsi - UMP), namely the minimum wage that applies to all districts / cities in one province;

2. Regency / City Minimum Wage (Upah Minimum Kabupaten/Kota - UMK), namely the minimum wage applicable in the regency / city area;

3. Provincial Sectoral Minimum Wage (Upah Minimum Sektoral Provinsi - UMSP), namely the minimum wage that applies sectorally in a province. Sectoral means the group of business fields and their division according to the Indonesian Standard Business Classification (Klasifikasi Baku Lapangan usaha Indonesia - KBLI); and

4. District / City Sectoral Minimum Wage (Upah Minimum Sektoral Kabupaten/Kota - UMSK), which applies to certain sectors in a district / city.

In the matter of determining the minimum wage, the governor as the head of the region has the authority to determine it by considering the recommendation of the provincial wage council. The basis for determining the minimum wage, according to Article 3 of the Permenakertrans, is the need for a decent life (Kebutuhan Hidup Layak - KHL) by taking into account productivity and economic growth. Apart from the UMP, the governor has the authority to determine the UMK with the consideration of the regent / mayor.Then, the Governor also has the authority to determine the UMSP and UMSK with the agreement of the company organizations and trade unions in the sector concerned. The stipulation is that the UMSP must not be lower than the UMP and the UMSK must not be lower than the UMK. The stipulation and announcement of the UMP by the governor is carried out simultaneously on November 1 every year. Meanwhile, UMK is determined and announced after the stipulation of the UMP, not later than November 21. The minimum wage takes effect from 1 January of the following year and, as stipulated, only applies to workers whose work period is less than one year.

Every company is obliged to pay its employees according to the minimum wage stipulated by the local government every year. According to the Manpower Act No. 13 of 2003, wages according to minimum standards are intended so that workers can earn an income that meets a decent living for humanity. Based on the Regulation of the Minister of Manpower and Transmigration (Permenakertrans) No. 7/2013 concerning Minimum Wages, the definition of minimum wages can be interpreted as the lowest monthly wage which consists of a basic wage including a fixed allowance determined by the governor as a safety net, and this wage must be used as a reference by employers and industry players as the minimum standard in providing wages for their workers.

\subsection{Description of Employment in Indonesia}

According to the Central Statistics Agency, the total number of Indonesian workers aged 15 years and over as of August 2019 was 126.51 million people. The largest distribution is found in informal workers, reaching 70.49 million people, and this figure is higher than formal workers, which is only 56.02 million (https: // databoks .katadata.co.id / datapublish / 2020/04/08 / the number of informal-workers-more-morethan-formal-workers. Accessed 9 September 2020) who are promoted as Regional Heads (Governor, Regent / Mayor). However, the problem that arises is how the leadership and preferences / preferences of the regional head with the minimum wage of workers / laborers. In this case, the definition of candidate pairs (Paslon) for Regional Heads who take part in the 2020 Pilkada contest is a leader candidate in public institutions in the region, and if elected will serve as Governor, Regent and Mayor (General Election Commission Regulation Number Regulation 3 of 2017) which has a very strategic role as a builder of public services in the regions in accordance with the constitution.

According to Katz, Kochan, \& Colvin (2015: 27), labor, management, and government are involved in complex interactions in developing countries, and this interaction greatly influences the evolution of work 
relations in these countries. Another way trade unions and workers influence the government is through their involvement in protests or other political actions that are part of a campaign or democratization movement (Katz, Kochan, \& Colvin (2015: 27). In the case of international labor relations, governments and employers often undermining labor rights while fighting for justice for all workers, demanding the needs and supporting the well-being of their own people, not at creating huge inequalities and huge profits for employers at the expense of workers in factories and in other business fields (Alliance for Global Justice's, 2020 ).

Indonesia is a country that has a large population, but until now Indonesia is still experiencing labor problems. As an example. the low quality of labor, the number of workers who are not proportional to employment opportunities, and the classic problem is the unemployment rate in Indonesia. However, there are still many things that need to be addressed in order to overcome problems related to employment. In Law No.13 / 2013 concerning manpower, it defines employment as everything related to labor before, during and after the work period.Based on the release of the Central Statistics Agency (2019), data which is information related to employment in Indonesia is described as follows:

1. The number of workforce in February 2019 was 136.18 million people, an increase of 2.24 million people compared to February 2018. In line with the increase in the number of the workforce, the Labor Force Participation (Tingkat Partisipasi Angkatan Kerja - TPAK) also increased by 0.12 percentage points.

2. In the past year, unemployment has decreased by 50 thousand people, in line with the Open Unemployment Rate (Tingkat Pengangguran Terbuka - TPT which fell to 5.01 percent in February 2019. Judging from the level of education, TPT for Vocational High Schools is still the highest among other education levels, which is 8,63 percent.

3. The working population is 129.36 million people, an increase of 2.29 million people from February 2018. Employment has experienced an increase in the percentage of the working population, especially in the provision of accommodation and food and drink ( 0.43 percentage points), Trade ( 0 , 39 percentage points), and Construction ( 0.34 percentage points). Meanwhile, the main decline in employment was in agriculture (1.00 percentage points); Government Administration (0.23 percentage point); and Information and Communication (0.06 percentage point).

4. As many as 74.08 million people (57.27 percent) worked in informal activities. Over the past year (February 2018 - February 2019), informal workers fell by 0.95 percentage points.

5. The highest percentage in February 2019 were full-time workers (minimum working hours of 35 hours per week) amounting to 69.96 percent. Meanwhile, the population who worked 1-7 hours had the lowest percentage, namely 2.69 percent. Meanwhile, part-time workers (22.67 percent) and semiunemployed workers ( 7.37 percent) are divided into two parts.

6. The average labor wage based on the results of the February 2019 Sakernas is 2.79 million rupiah.

7. The average wage for male workers is 3.05 million rupiah and the average wage for female workers is 2.33 million rupiah.

8. There are 7 out of 17 job categories with an average labor wage lower than the national average wage.

9. The average wage for university educated workers is 4.34 million rupiah, while workers with elementary school education (Sekolah Dasar) and below are 1.73 million rupiah.

Then, employment problems can arise due to several factors such as education, employment opportunities and relatively low economic growth. This is experienced by many countries, including Indonesia, because until now there are still many unemployed people or more precisely people who cannot work because of the lack of employment (Silalahi, 2020). According to Silalahi (2020), there are three labor problems that often occur in Indonesia as follows: (1) Number of Unemployment - Due to the high population and not enough employment opportunities, this problem is the most important in Indonesia. Likewise, the low quality of labor and economic growth are the main factors in the emergence of this problem. (2) Low Employment Arises from the number of productive labor force that is not proportional to the number of jobs provided. This is one of the triggers for the unemployment problem.; and )3) Low Quality of Workforce - Low level of education, both formal and non-formal. The economic capacity of the Indonesian people is classified as low causing the inability to obtain higher education. 
Therefore, manpower planning as a strategic planning concept in the government and public sectors is indispensable to address issues related to manpower. According to experts in Obisi, Samuel, \& Ilesanmi (2018: 2). defining workforce planning is human resource planning in order to improve organizational performance and efficiency because most organizations face both human and resource challenges from time to time. Then, the need to have an effective workforce planning strategy that can bypass any constraints that may materialize in the process of operating a business, because every organization whether public, private or non-governmental organization (NGO) has limited resources, materials are scarce, labor, capital, machines, among others. Thus, in terms of determining policies and formulating manpower planning programs, the Government of Indonesia has grouped them into two groups (Disnakertrans. Banten Province, 2020) as follows:

1. Macro manpower planning is a systematic manpower planning using optimal and productive manpower to stimulate growth. The growth referred to here is economic and social growth at a national, regional, and sectoral scale which can open the widest possible job opportunities, so as to increase the productivity and welfare of workers.

2. Micro workforce planning has a smaller scope. The scope referred to here is only limited to the scope of the institution, be it government or private companies. In terms of the understanding between macro and micro manpower planning, they have similarities. In terms of micro worker planning, the definition is systematic manpower planning within an agency, government or private. Aiming at the use of optimal and productive manpower to achieve higher performance in related agencies.

Therefore, strategic efforts are needed related to the development of human resources (HR), the development of creative industries and programs that support small and medium enterprises (SMEs) so that they can become an option in overcoming labor problems. On the other hand, one that is very crucial in interpreting the definition of labor is the optimal and efficient use of labor. Therefore, a manpower planning is needed which aims to carry out a manpower plan systematically and serve as a reference in formulating policies, strategies and programs. other manpower development on an ongoing basis.

Thus, the workforce planning program carried out by the government, in the end can not only benefit workers / laborers but also benefit the company because continuity in production and productivity can be guaranteed as well as the development of creative industries and programs that support small and medium enterprises.. According to Thaha (2020: 148), the contribution of SMEs to the Indonesian economy is very large in various fields, including: (1) The number of business units in Indonesia as of 2018 has a total of 64.2 million business units, with the number of Micro Small and Medium Enterprises (MSME) business units of 64.1 million. (99.9\%), and (2) Contribution to the number of workers, the number of workers in Indonesia as of 2018 totals 120.6 million people, with the number of workers in MSMEs of 116.9 million $(97 \%)$.

\subsection{Regional Head Leadership and Preferences}

According to the Law of the Republic of Indonesia Number 22 of 1999 concerning Regional Government, the definition of Regional Government is the Regional Head and other Autonomous Region apparatuses as Regional Executive Bodies (Article 1 letter b), and Regional Government is the administration of Autonomous Regional Government by the Regional Government and DPRD. according to the principle of decentralization (Article 1 letter d). The definition of decentralization is the delegation of governmental authority by the Government to the Autonomous Region within the framework of the Unitary State of the Republic of Indonesia (Article 1 letter e), while the meaning of Co-Administration is the assignment from the Government to Regions and Villages and from Region to Village to carry out certain tasks accompanied by financing, facilities. and infrastructure and human resources with the obligation to report on the implementation of them and to be accountable to the assignment (Article 1 letter $\mathrm{g}$ ),

Then, the definition of Regional Autonomy is the authority of the Autonomous Region to regulate and manage the interests of the local community according to their own initiative based on the aspirations of the community in accordance with the laws and regulations ((Article 1 letter $h)$. which has certain regional boundaries, has the authority to regulate and manage the interests of the local community according to their own initiatives based on the aspirations of the community within the ties of the Unitary State of the Republic 
of Indonesia. (Article 1 letter i), and the meaning of Administrative Region is the working area of the Governor as the representative of the Government. (Article 1 letter $\mathrm{j}$ ),

According to the Law of the Republic of Indonesia Number 23 of 2014 (RI Law No.23 of 2014) concerning Regional Government, Regional Government is the regional head as an element of Regional Government administering who leads the implementation of government affairs which become the authority of autonomous regions (Article 1 paragraph 3). Then, the authority of the Regional Head related to labor is regulated in RI Law No.23 of 2014 Article 12 paragraph (2) as well as Mandatory Government Affairs as referred to in 11 paragraphs (1) and (2) consisting of Government Affairs related to Basic Services and Government Affairs that are not related to Basic Services .. In the case of Sectoral Minimum Wages, Article 88 paragraph (1) and (2) Law Number 13 Year 2003 concerning Manpower reads: (paragraph 1) Every worker / laborer has the right to earn an income that meets decent living for humanity, and (paragraph 2) In order to realize an income that fulfills a life worthy of humanity as referred to in paragraph (1), the government establishes a wage policy that protects workers / laborers.

Furthermore, one of the wage policies is the minimum wage which includes the provincial or district / city minimum wage and the sector minimum wage in the province or district / city. (Article 89 paragraph (1) in conjunction with Article 88 paragraph (3) letter (a) of the Law 13 of 2003 concerning Manpower), and provisions regarding wages are further regulated in Government Regulation (PP) Number 78 of 2015 concerning Wages, Article 49 states that:

1. The governor may determine the provincial and / or district / municipal sectoral minimum Wage based on the agreement between the employers' association and the trade / labor union in the sector concerned.

2. The determination of the sectoral minimum wage as referred to in paragraph (1) shall be made after obtaining suggestions and considerations regarding the leading sector from the provincial wage councils or regency / municipal wage councils in accordance with their duties and authorities.

3. Provincial sectoral minimum wage as referred to in paragraph (1) must be greater than the provincial minimum Wage in the province concerned.

4. District /city sectoral minimum wage as referred to in paragraph (1) must be greater than the district / city minimum wage in the regency / city concerned.

Further provisions regarding sectoral minimum wages are further regulated in the Minister of Manpower Regulation Number 15 of 2018 (Permenaker 15/2018) concerning Minimum Wages. According to Article 1 number 5 Permenaker 15/2018 the definition of Provincial Sectoral Minimum Wage (UMSP) is the minimum wage that applies to certain sectors within the region of 1 (one) province, and the meaning of Regency / City Sectoral Minimum Wage (UMSK) is the applicable minimum wage for certain sectors within the region of 1 (one) district / city (Article 1 number 6 Permenaker 15/2018) as well as UMSP and / or UMSK valid since stipulated by the Governor. (Article 12 paragraph (4) Permenaker 15/20184).Wages play a very important role and become a special thing in a work relationship so that the essence of wages becomes the main goal of a worker who does work for another person or legal entity. Given the strategic position of wages, the government has a significant influence on work relations through laws and public policies that regulate the implementation of work relations (Katz, Kochan, \& Colvin, 2015: 28), namely the determination of labor wages to obtain income that is decent for humanity. .. On the other hand, a poorly designed minimum wage can jeopardize the welfare of workers / laborers, undermine effective implementation, and risk encouraging informality (International Labor, 2016: 2).

According to International Labor (2016: 2), the objectives of minimum wages are to: (1) protect workers from unduly low wages, (2) help to ensure a fair and equitable share of progress for all, (3) become wrong one policy element for tackling poverty and reducing inequality, including between men and women, by promoting the right to equal pay for work of equal value. On the other hand, the minimum wage system should not be viewed or used in isolation, but must be designed in such a way as to complement and strengthen other social and labor policies, can be used to address income and labor market inequalities, including pro-employment policies, social transfers, and creating an enabling environment for sustainable companies (International Labor Organization, 2016: 4)). Furthermore, wage arrangements are determined on 
the basis of an agreement between employers and workers (Siswanto, 2010: 15), and the government establishes protection with wages for workers in order to realize decent income.

Based on the various descriptions above, it can be interpreted that the Regional Head as regulated by various applicable laws and regulations is the authority or authority to determine and determine policies related to the welfare of workers / labor such as minimum wages and so on. Thus, the leadership and preferences / alignments of the Regional Head as a political leader in the public domain in state institutions as well as transformational leaders in the regions are expected to provide solutions related to labor problems that arise due to several factors such as minimum wages for necessities and support for a decent living. , education, job opportunities, and other injustices at work.

\section{Conclusions and Recommendations}

The regional head has the authority to set the minimum wage by considering the recommendation of the provincial wage council. The basis for determining the minimum wage, according to Article 3 of the Permenakertrans, is the need for a decent life (kebutuhan hidup layak - KHL) by taking into account productivity and economic growth. Apart from the UMP, the governor has the authority to determine the UMK with the consideration of the regent / mayor as well as the authority to determine the UMSP and UMSK. Then, the regional head as a public leader and also as a transformational leader is expected to be able to provide solutions related to labor problems that arise due to several factors such as the minimum wage as mandated by Article 27 paragraph (2) of the Constitution of the Republic of Indonesia (UUD NRI). In 1945, states that, "Every citizen has the right to work and a living that is decent for humanity" especially for workers / laborers in order to meet their needs and support a sufficient life, education, job opportunities and other injustices in work.

In other words, the minimum wage in the form of adequate salaries and allowances that is received as a whole is very important to support the physical life of workers / laborers and their families in order to meet the decent living needs of workers / laborers and their families. This is the essence of the goal of the minimum wage (Article 27 paragraph (2) of the Constitution of the Republic of Indonesia, Law Number 13 of 2003; International Labor Organization, 2016: 2; Katz, Kochan, \& Colvin, 2015: 28, Budd, J. W., \& Spencer, D. A., 2014:189)). Furthermore, regional heads are expected to make innovative efforts related to human resource development (HR), creative industry development and programs that support small and medium enterprises (SMEs) so that they can be one of the options in overcoming labor problems.

\section{References:}

[1.] Alliance for Global Justice’s. (2020). afgj@afgj.org ((Accessed on September 14, 2020).

[2.] Babbie Earl .(1989). The Practice Of Social Research. California: Wadsworth Publishing Company.

[3.] Badan Pusat Statistik .(2019). Februari 2019: Tingkat Pengangguran Terbuka (TPT) sebesar 5,01 persen (https://www.bps.go.id/pressrelease/2019 /05/06/ 1564/februari-2019--tingkatpengangguran-terbuka--tpt--sebesar-5-01-persen.html. (Accessed on 12 September 2020).

[4.] Bass, B. M. (1985) Leadership and performance beyond expectations. New York: Free Press.

[5.] Bass, B. M., \& Avolio, B. J. (1990). The implications of transactional and transformational leadership for individual, team, organizational development. Research in Organizational Change and Development, 4, $231-272$.

[6.] Bass, Bernard. M. and Ruth Bass. (2009). The Bass Handbook of Leadership: Theory, Research, and Managerial Application. 4th ed. New York. Free Press.

[7.] Belle,Nicola.(2013). Leading to Make a Difference: A Field Experiment on the Performance Effects of Transformational Leadership, Perceived Social Impact, and Public Service Motivation. Journal of Public Administration Research and Theory 24(1):109-136 DOI:10.1093/jopart/mut033https://www.researchgate.net/publication/ 274999852_Leading to_Make_a_Difference_A_Field_Experiment_on_the_Performance_Effects_ of_Transformational_Leadership_Perceived_Social_Impact_and_Public_Service_Motivation (Accessed on 8 September 2020) 
[8.] Budd, J. W., \& Spencer, D. A. (2014). Worker well-being and the importance of work: Bridging the gap. European Journal of Industrial Relations, 21(2), 181-196. doi:10.1177/0959680114535312 (Accessed on 10 September 2020).

[9.] Bums, J. M. (1978) Leadership. New York: Harper \& Row.

[10.] Colquitt, Jason A., Jeffery A. LePine, and Michael J. Wesson. (2011)..Organizational Behavior. New York: McGraw-Hill,

[11.] DiFranza, Ashley .(2019). Transformational Leadership: How To Inspire Innovation In The Workplace. University Graduate Programs. https://www.northeastern.edu/graduate/blog/transformational-leadership/ (Accessed on 14 September 2020.

[12.] Disnakertrans Provinsi Banten. (2020). Pengertian Ketenagakerjaan Dan Penting Unsurnya . https://disnakertrans.bantenprov.go.id/Berita/topic/306 (Accessed on 12 September 2020)

[13.] Ford, Michele. (2000). Reseach Note : Indonesian Trade Union Development Since the Fall of Suharto, Journal Labour and Management in Development, Vol. 1 Number 3, Asia Fasific Press, Australian National University. https://openresearch-repository anu. edu.au/bitstream/1885/41131/2/1-3-ford.pdf (Accessed on 10 September 2020).

[14.] Hamid, Adnan.(2020). Analysis of theImportance ofOmnibus Law "Cipta Kerja" In Indonesia. International Journal of Scientific Research and Management (IJSRM)||Volume||08||Issue||08||Pages||LLA-2020-236-250||2020||Website:www.ijsrm. in ISSN (e): 2321-3418DOI:10.18535/ijsrm/v8i08.1la01 ijsrm/article/view/2877/2140 (Accessed on 10 September 2020).

[15.] --- (2019). Protection Of Indonesian Domestic Workers: A Study Of Law No. 13 Of 2003 Concerning Labor. International Journal of Scientific \& Technology Research.https://www.ijstr.org/paper-references.php?ref=IJSTR-0819-21059 (Accessed on 10 September 2020).

[16.] Harian Kompas, Calon Tunggal Bajak Demokrasi, Politik \& Hukum , Terbitan 12 September 2020, halaman 3.

[17.] Interrnational Labor Organization - ILO. (2016). Minimum wage policy guide A summary. https://www.ilo.org/wcmsp5/groups/public/---dgreports/---dcomm/---publ/documents /publication/wcms 570376.pdf (Accessed on 15 September2020)

[18.] Iqbal, Qaisar. (2016). Organizational Politics, Transformational Leadership and Neglect in Banking Sector . International Journal of Management, Accounting and Economics Vol. 3, No. 10, October, $2016 \quad$ ISSN 2383-2126. file:///C:/Users/user/Downloads /OrganizationalPoliticsTransformationalLeadershipandNeglectinBankingSector.pdf (Accessed on 15 September2020)

[19.] Jones, Gareth R. \& George, Jennifer M., (2013). Essentials of Contemporary Management, Fifth Edition. United States of America : McGRAW-Hill International.

[20.] Jumlah Pekerja Informal Lebih Banyak dari Pekerja Formal. https://databoks.katadata. co.id/ datapublish/ 2020/04/ 08/jumlah-pekerja-informal-lebih-banyak-dari-pekerja-formal. (Accessed on 9 September 2020).

[21.] Kartono, Kartini .(2010). Pemimpin dan Kepemimpinan. Jakarta: PT. Raja Grafindo Perkasa.

[22.] Katz,,Harry C.; Kochan ,Thomas A.; Colvin, Alexander.(2015). Labor, Management, and Government Interactions. Cornell University ILR School DigitalCommons@ILR. https://digitalcommons.ilr. cornell.edu/articles (Accessed on 12 Sepetember 2020).

[23.] Kuncahyo, Wahyu Sabda. (2016). Buruh Jangan Salah Pilih Kepala Daerah Laporan: Minggu, 21 Agustus 2016, 16:07 WIB Rmol.id, https://politik.rmol.id/ read/2016 /08/21/257759/BuruhJangan-Salah-Pilih-Kepala-Daerah- .(Accessed on 12 Sepetember 2020).

[24.] Lollo N, O'Rourke D. (2020). Factory benefits to paying workers more: The critical role of compensation systems in apparel manufacturing. PLoS ONE 15(2): e0227510. https://doi.org/10.1371/journal.pone.0227510. $\quad$ https://journals.plos.org/plosone/article ?id=10.1371/journal.pone.0227510 (Accessed on 10 September 2020)

[25.] McFarland, Andrew S. (1987). Interest groups and theories of power in America. British Journal of Political Science 17: 129-47 DOI: https://doi.org/10.1017/S0007 1234 00004683Published online 
by Cambridge University Press: 27 January 2009 https://www.cambridge.org/core/journals/britishjournal-of-political-science/article/ interest-groups-and-theories-of-power-in-america /C03D59F436C12C158AFA13 CB 89EFAF6D (Accessed on 12 Sepetember 2020).

[26.] Mahasin, Z. Z., Naziah, F., \& Arifin, R. (2020). Wage Problems in Indonesia in the Human Rights Perspective (Case of Inappropriate Wages for Pot Workers in Tangerang). The Indonesian Journal of International Clinical Legal Education, 2(1), 1-14. https://doi.org/10.15294/ijicle.v2i1.37326 (Accessed on 9 September 2020).

[27.] Manullang, Sendjun H., (2001).Pokok-pokok Hukum Ketenagakerjaan di Indonesia, Jakarta: Rineka Cipta,

[28.] Mikkelsen, Maria Falk; Jacobsen Christian Bøtcher; \& Andersen, Lotte Bøgh. (2015). Managing Employee Motivation: Exploring the Connections Between Managers' Enforcement Actions, Employee Perceptions, and Employee Intrinsic Motivation, International Public Management Journal, DOI: 10.1080/10967494.2015.1043166 ISSN: 1096-7494 (Print) 1559-3169 (Online) Journal homepage: http://www.tandfonline.com/loi/upmj20 (Accessed on 8 September 2020).

[29.] Moleong. Lexy J. (2002). Metodologi Penelitian Kualitatif. Bandung : Remaja Rosda Karya.

[30.] Morrell, K., \& Hartley, J. (2006). A model of political leadership. Human Relations, 59(4), 483$504 . \quad$ doi:10.1177/0018726706065371 https://journals.sagepub.com/doi/10.1177/ 0018726706065371 (Accessed on 15 September 2020).

[31.] Mudassir, Rayful (24 Juni 2020). "Ini Jadwal Lengkap Tahapan Pilkada Serentak 2020 Terbaru". Bisnis.com. (Accessed on 27 Juni 2020).

[32.] Muhammad, Abdulkadir . (2004). Hukum dan Penelitian Hukum, Bandung: PT. Citra Aditya Bakti

[33.] Nye, Joseph. (2008). The Powers to Lead. Oxford: Oxford University Press.

[34.] Oberfield, Zackary W. (2014). Public Management in Time: A Longitudinal Examination of the Full Range of Leadership Theory. Journal of Public Administration Research and Theory 24(2):407-429. DOI: 10.1093/jopart/mus060. https://www.researchgate.net/ publication/279406481_Public_Management_in_Time_A_Longitudinal_Examination_of_the_Full Range_of_Leadership_Theory (Accessed on 8 September 2020).

[35.] Peraturan Komisi Pemilihan Umum Republik Indonesia Nomor 3 Tahun 2017 Tentang Pencalonan Pemilihan Gubernur Dan Wakil Gubernur ,Bupati Dan Wakil Bupati, Dan Atau Walikota Dan Wakil Walikota.

[36.] Peraturan Pemerintah Nomor 78 Tahun 2015 tentang Pengupahan.

[37.] PUSAT ANALISIS DAN EVALUASI HUKUM NASIONAL BADAN PEMBINAAN HUKUM NASIONAL KEMENTERIAN HUKUM DAN HAM RI TAHUN 2018. file:///D:/pokja_peraturan_peruuan_ketenagakerjaan.pdf (Accessed on 15 September 2020).

[38.] Rafferty, A. E., \& Griffin, M. A. (2004). Dimensions of transformational leadership: Conceptual and empirical extensions. The Leadership Quarterly, 15(3), 329-354. doi:10.1016/j.leaqua.2004.02.009 . . https://www.sciencedirect.com/science/article /pii/S1048984304000207 Accessed on 15 September 2020).

[39.] Ravi, S: \& Raja, J.A. (2016). A Study on Employee Welfare Measures with Reference to Small Scale Industries at Hosur, Tamilnadu. IJSR - International Journal Of Scientific Research Volume : \begin{tabular}{l|lll|lllllll}
5 & Issue & $:$ & 1 & January & 2016 & $\bullet$ & ISSN & No & 2277 & -
\end{tabular} https://www.worldwidejournals.com/international-journal-of-scientific-research(IJSR)/fileview.php?val=January_2016_1451553304_28.pdf (Accessed on 8 September 2020).

[40.] Robbins, Stephen P and Judge, Timothy A. (2015). Organizational Behavior. $16^{\text {th }}$ Edition .. Pearson. United State America.Edisi 16. Penerbit Salemba Empat : Jakarta.

[41.] Silalah,i M. Daud .(2020). Ketenagakerjaan: Pengertian, Peraturan \& Masalahnya. https://www.dslalawfirm.com/pengertian-masalah-peraturan-ketenagakerjaan/ .( Accessed on 12 September 2020).

[42.] Siswanto, Sastrohadiwiryo B.(2010). Manajemen Tenaga Kerja Indonesia pendekatan Administrasi dan Operasional, Cetakan. 2, Bandung : Penerbit PT.Citra Aditya,

[43.] Soekanto, Soerjono dan Sri Mamudji (2006). Metode Penelitian Hukum Normatif, Jakarta: Rajagrafindo Persada.

[44.] Soepomo,Imam. (1999). Pengantar Hukum Perburuhan, Djambatan, Jakarta. 

Djambatan, Jakarta.

[46.] Thaha, Abdurrahman Firdaus. (2020). Dampak Covid-19 Terhadap UMKM di Indonesia . Jurnal Brand, Volume 2 No. 1, Juni -ISSN : 2715-4920. https://ejournals.umma .ac.id /index.php/brande. (Accessed on 8 September 2020).

[47.] The World Bank, Doing Business 2018: Reforming to Create Jobs . Washington, DC: World Bank Publications,

[48.] Tucker, Robert C. (1995). Politics as Leadership. Missouri: University of Missouri Press.

[49.] Tummers, Lars; \& Knies, Eva. (2016). Measuring Public Leadership: Developing Scales for Four Key Public Leadership Roles. Public Administration. DOI: 10.1111/padm.12224 https://www.researchgate.net/publication/281372135 (Accessed on 8 September 2020).

[50.] Undang Undang Dasar Negara Republik Indonesia Tahun 1945,

[51.] Undang - Undang Nomor 13 Tahun 2003 tentang Ketenagakerjaan.

[52.] Undang-Undang Republik Indonesia Nomor 23 Tahun 2014 Tentang Pemerintah Daerah.

[53.] Undang - Undang Republik Indonesia Nomor 22 Tahun 1999 Tentang Pemerintah Daerah.

[54.] Waas, B. (2010). The Legal Definition of the Employment Relationship. European Labour Law Journal,1(1),45-57. doi:10.1177/201395251000100105.https://journals.sagepub. com/doi/abs/10.1177/201395251000100105 (Accessed on 8 September 2020).

[55.] Wheelen, Thomas L. ; and J. David, Hunger (2012). Concept in Strategic Management and Business Policy: Toward Global Sustainability, Thirteenth Edition , Upper Saddle, New Jersey.

[56.] Yukl, Gary .A. (2010), Leadership in Organizations, Prentice Hall Inc.,Englewood Cliffs New Jersey. 